\title{
How to Deal with Non-Dominant Languages - Metalinguistic Discourses on Low German in the Nineteenth Century*
}

\author{
Nils Langer (Flensburg/Bristol) and Robert Langhanke (Flensburg/Kiel)
}

\begin{abstract}
This paper discusses nineteenth-century metalinguistic discussions of Low German, an authochthonous of Northern Germany, which, having lost its status as a written language suitable for formal discourse during the Early Modern period, has since been reduced to the spoken domain. During the nineteenth century the language was on the verge of enjoying a revival, with original poetry being published and extensive discussions as to whether Low German ought to play a role in formal education. As this article shows, this discussion was intense and controversial. Comparing the views of Klaus Groth, the leading proponent of Low German in the second half of the nineteenth century, with the internal debates amongst school teachers - hitherto never discussed by the scholarly literature - this article demonstrates the intellectual and ideological split felt by these educational practioners in their views of Low German: on the one hand, they recognise the cultural value of Low German as the historical language of the North and the native language of the pupils they teach, on the other hand they agree with each other that the language of education and science, as well as national unity, can only be High German. We hope to show with our discussion not only how very similar modern thinking on the use of Low German is to these historical discussions but also how the status and perception of many regional and minority languages across the world has been subject to the same or very similar thoughts and pressures.
\end{abstract}

\section{$1 \quad$ Introduction}

After decades and centuries of discrimination and invisibilisation, many minority and regional languages have seen a resurgence in acceptability and social status in the last two or three decades. Political measures such as the signing and ratification of the European Council's Charter for the Protection of Regional or Minority Languages are often seen as rubberstamping, rather than initiating changes in the perception of non-dominant languages. However, despite an overall much more positive perception of minority and regional languages as cultural treasures, elements of community identity, and something worth holding on to, actual usage continues to decline for most of these languages. This is certainly the case for the protected languages of northern Germany; Frisian, South Jutish, and Low German. This curious tension between emotional and cultural support for smaller or non-dominant languages and a failure to do what might actually help them, i. e. speaking these languages, is nothing new. A glance at their recent sociolinguistic history may show us that this tension did not only emerge in the late twentieth century but has, in fact, been part of the sociolinguistic landscape at least since the Age of Romanticism. In particular we show how literary scholars, representing language theoreticians, and school teachers, representing language practitioners,

\footnotetext{
* We are grateful to the audience of ICML 2012 and the anonymous reviewers for Linguistik Online for valuable comments and to Jennifer Roberts (Norwich) for help with the translations and our idiosyncratic command of the English language.
} 
were simultaneously engaged in very similar debates on the status and usefulness of nondominant languages, albeit with very different results.

In this context, our paper will present metalinguistic comments on Low German from the mid-nineteenth century to discuss to what extent perceptions of the language, including views on its practical use, were different from those we find today. We will focus on two sets of data: firstly, a collection of open letters aimed at a learned readership written by the Low German poet and professor, Klaus Groth (1819-1899), on the status and usability of the language, and secondly, accounts of metalinguistic discussions on Low German by elementary-school teachers (Volksschullehrer) published in their semi-public ${ }^{1}$ weekly association magazine. By analysing and comparing the two we will acquire an understanding of popular views on contemporary multilingualism in the $1850 \mathrm{~s}$ and $-60 \mathrm{~s}$, and detect both significant differences and similarities with comparable situations familiar to us from today, not just as regards Low German, but non-dominant languages more generally.

\section{Low German in 19th-century Schleswig-Holstein}

The nineteenth century proved a time of great turmoil for Schleswig-Holstein, nowadays the name of the northernmost region of Germany but until 1864 a part - through various constitutional arrangements - of Denmark and, after a short period of occupation until 1867, a province of Prussia until the end of WWI. ${ }^{2}$ Famous for its quintolingual regions on the west coast, where some extended families still use Frisian (Frasch), Low German (Plattdüütsch), High German (Hochdeutsch), South Jutish (Sønderjysk), and Standard Danish (Rigsdansk), the principal language contact and language conflict in the nineteenth century pertained to German vs. Danish, where in both cases the respective standard languages as the only permissible written forms were generally meant. ${ }^{3}$ Having peacefully co-existed for centuries before, the nineteenth century saw the instrumentalisation of languages as a key factor in determining national identity and allegiance:

Das Herzogtum Schleswig, das seit dem Mittelalter ein [...] Sprachkontaktgebiet gewesen war, entwickelte sich im 19. Jh. deutlich zu einem Gebiet des Sprachkonflikts, wo Sprache zunehmend [...] zum ideologischen Instrument politischer Auseinandersetzungen gemacht wurde. (Dyhr 1998: 101)

'Having been a region of language contact since the Middle Ages, the Duchy of Slesvig turned into a region of language conflict during the nineteenth century, where language was used increasingly as an ideological tool for political debates.'

Whilst the German-Danish language conflict of the nineteenth century has attracted significant interest from historians because of its constitutional and military dimensions (Bracker 1972/3; Rohweder 1976; Petersen 1995), much less attention has been paid to the use and status of the non-standard languages of Low German and Sønderjysk at the time (but cf. Fredsted 2003; Langer 2011).

In this paper we will focus on one of these languages, the case of Low German, the mother tongue of "German" speakers in Schleswig-Holstein. The language is the only language in Germany protected as a "regional language" by the European charter ${ }^{4}$ and boasts a number of

\footnotetext{
${ }^{1}$ Whilst the magazine was free for anyone to buy, most subscribers and readers were fellow school teachers.

2 The details of these constitutional arrangement are not relevant here; for a summary cf. Dyhr 1998.

3 The observation that in an area with three indigenous languages (Frisian, South Jutish, and Low German), the primary conflict related to two other, non-indigenous languages is worth noting but will discussed at greater length in a separate article.

${ }^{4}$ Germany ratified the Charter in 1998. Cf. Menke 1998 and 2001 for reasons given to demonstrate the particular status of Low German, as compared other non-standard linguistic varieties in Germany.
} 
political and cultural associations and activities aimed at its preservation and promotion. In contrast to the minority languages Frisian and Sønderjysk, it has been used throughout the north German area and is not affiliated with any particular ethnicity or nation. ${ }^{5}$ Texts in Low German (Old Saxon) survive from the ninth century and the language was used as the primary written vernacular in the area throughout the Middle Ages. It rose to particular prominence as the lingua franca of the Hanseatic League when it was used across linguistic boundaries in Northern Europe, especially in the later fourteenth and fifteenth centuries. From the sixteenth century came the decline ${ }^{6}$ of the language and its loss of the written domain, and we find first metalinguistic comments on the ongoing pejoration of Low German (Nathan Chytraeus 1582; cf. Arendt 2010: 49). In the seventeenth and eighteenth centuries, evidence of written Low German can only really be found in comic and ridiculing writing. ${ }^{7}$ By the early nineteenth century, Low German had been reduced to a purely oral language though still used as a first and native language amongst the middle or even upper classes. From this period we find a number of commentators highly critical of the language.

The seventeenth- and eighteenth-century view that languages had a particular character or spirit (Sprachgenius, Sprachgeist) continued to prevail in the nineteenth century. For this century, Arendt (2010) identified four principal arguments aimed at reducing the value and usage of Low German.

(i) Languages were seen to instantiate and personify particular moral or physical properties of their speakers and, in particular in the context of the writings by Johann Gottfried Herder and Johann Gottlieb Fichte, their nations. The desired creation of a unified German nation required the existence of a - single and uniform - national language and the only plausible candidate for this was High German.

(ii) The linguistic properties of a language were argued to permit or restrict the intellectual advancement of its community of speakers. A person's perception of the external world was thus different depending on one's native language, both because of differences in lexical items but also structural differences between languages (cf. Wilhelm von Humboldt 1836). This view of languages had significant repercussions for the assessment of dialects as they were viewed as deficient as regards their cognitive functions and thus restricted their speakers in expressing themselves at an advanced level.

(iii) The backwardness of Low German was "demonstrated" by historical linguists who were interested in contemporary dialects because of their ancient and archaic features and constructions. Whilst in previous centuries - but also later on - this argument was also used positively, namely to show Low German's ancient lineage and linguistic purity (because it preserved old constructions), in the first half of the nineteenth century it was used to show the unsuitedness of the language for a modern and progressive society.

(iv) The potential for educating (Bildungsfähigkeit, cf. Arendt 2010: 78) a people was dependent on the linguistic properties of their language; only standard or 'big' (= national) languages, which had been "shown" (by history) to be able to deliver advanced education, ${ }^{8}$ could be permitted to be used in this domain. In other words, educational establishment such as schools but also, by extension, any official institutions, had to remain dialect-free. Some

\footnotetext{
5 Although the idea of a Low German ethnic identity or a Low German people had been voiced at different stages in history.

6 To what extent the Reformation can be seen as the principal cause of the decline is still unclear (cf. Langer 2003 for a summative account).

7 Raupach 1704, Richey 1755, Dähnert 1781 form rare exceptions though none of these texts were actually written in Low German (cf. Stammler 1918).

8 Interestingly, High German itself only became a language of education in the eighteenth century, with the decline of Latin as the language of universities and grammar schools.
} 
commentators such as Ludolf Wienbarg (1834, cf. Schuppenhauer 1980) and Gustav Flörke (1825, cf. Arendt 2010) argued even further. Because the continued use of Low German - as the local dialect - prevented the emancipation of the lower classes, it would effectively cement the sociolinguistic division of High German as a the language of official and formal discourse and Low German as the language not just of orality in general but also sociolinguistically marked as the language of the uneducated and peasants. In order to lift the lower classes and enable them to participate in higher societal interaction, e.g. when giving evidence at court, it was important that they spoke High German, and in consequence, the only solution would be the extermination of Low German.

Our sources for metalinguistic comments on Low German until the middle of the nineteenth century come largely from intellectuals; the view from below is difficult to ascertain as such sources are scarce and have so far escaped the attention of historical linguists. ${ }^{9}$ It is striking, however, that a great many comments from intellectuals (pastors, higher-level teachers, writers) are fairly critical of the usefulness of Low German. The overwhelming position appears to be that the use of Low German is to be discouraged, either because of its low status as a rural or peasant language as such, or because of its sociolinguistic status that provides an obstacle to the emancipation of the lower classes. This view becomes fundamentally and successfully challenged during the nineteenth century and finds its most vocal and successful proponent in the figure of Klaus Groth (1819-99) in the second half of the century. His poetry in Low German and, to a lesser extent, his metalinguistic writing on the use of Low German, paved the way for a radical re-evaluation of Low German. However, such ideas were not always met with general approval. In what follows, we will present Groth's views on the role of Low German in Northern German culture, education, and nation-building and then contrast these with discussion amongst elementary-school teachers, i. e. those who, on a daily basis, faced the problem of teaching pupils in High German, whose native and family language was Low German.

\section{$3 \quad$ Klaus Groth}

Klaus Groth came from a modest background in Dithmarsia, on the west coast of Holstein, and worked as a scribe in a small parish. Despite only moderate schooling, he developed a keen interest in academic subjects and read widely in the humanities, arts, and natural sciences. He published a collection of poems in Low German in 1852 - Quickborn - which was amongst the first serious and widely-received writing in the language for some 200-300 years and which is still well-known today (cf. Stammler 1920). He devised his own orthographic system for this purpose, which was adopted by other writers in the second half of the century and he became a vocal advocate of Low German, who continues to be wellknown in Northern Germany to this day. ${ }^{10}$

Apart from the publication his original poetry, ${ }^{11}$ Groth is fairly unique amongst his literary peers in that he also wrote more theoretically on the value, usefulness, and linguistic functionability of Low German. His first and most significant contribution are his Briefe über Hochdeutsch und Plattdeutsch ('Letters on High German and Low German'), a collection of 26 open letters published in 1858 but he returned to the topic again from time to time. Apart

\footnotetext{
${ }^{9}$ This lack of resources is currently being addressed by a research project (Kiel - Flensburg - Bristol) which aims, amongst other things, to collect and publish primary sources in order to present the view from below (www.spsh.uni-kiel.de).

${ }^{10} \mathrm{Cf}$. Bichel et al. (1994) for a comprehensive account of Klaus Groth's biography and his literary contributions.

${ }^{11} \mathrm{He}$ is, of course, much better known for his original poetry in Low German which marked the beginning of the Neuverschriftlichung, i.e. the conscious and artistic production of Low German written texts. Groth has remained an important figure in Northern Germany and his poetry continues to be read in schools and literary festivals today.
} 
from this source, we will also provide evidence from three of his other publications, his Erhaltung der Volkssprache ('Protecting the Vernacular', 1865-6), his preface to his edition of Franz Giese's work (1878), and his 1889/1899 Wie mein Quickborn entstand ('On the making of Quickborn'). His arguments in support of Low German are intertwined and overlapping and we identified a number of key topics and lines of argumentation, which are fairly consistent in their general tenor across the sources we use, despite the fact that they were written at different stages of his life. In what follows, we will present his thinking in a selection of quotations from these sources, to show his principal positions on the metalinguistics of Low German.

The primary line of argument employed by most pro-Low German commentators is to suggest or show that it is a language, rather than a mere dialect of (High) German. This is often done e.g. with reference to its glory days when it was used as a lingua franca in the late Middle Ages - and thus undoubtedly as a language in its own right. Groth, too, uses this argument and claims that such proud use cannot simply be lost in time:

Die plattdeutsche Sprache hat einmal mit der Hansa die Welt beherrscht, sie beherrscht noch das Meer oder teilt die Herrschaft mit ihrer Halbschwester, dem Englischen. [...] Das verschwindet nicht wieder aus ihrem stolzen Gang. (18th letter, p. 110)

'With the Hanseatic League, Low German once dominated the world and it still rules the sea or at least shares it with its half-sister English. [...] Something like that doesn't simply vanish from its proud stride.'

However, more prominent arguments during the Age of Romanticism and beyond relate to the inherent qualities of a language, which are at least equal if not superior to a competing language. ${ }^{12}$ In particular, it was believed that any language would engage in a direct correlation with the nature or spirit of the people who spoke it. This belief is particularly wellknown from Johann Gottlieb Fichte (1762-1814) and Johann Gottfried Herder (1744-1803) at the beginning of the nineteenth century but it carries on for decades to go. Groth, too, sees this correlation between language and people:

Denn Sprache und Volksgeist sind eins und dasselbe. (9th letter, p. 91)

'Language and the spirit of the people are one and the same.'

A related topic concerns the age of languages, cultures, and people, as it was discussed particularly in the seventeenth and eighteenth centuries when linguistic perfection was often equated with ancient age: the older a language, the more perfect it was considered to be (cf. Eco 1994; Gardt 1999). This reference to age as a marker of quality can be found in Groth's writings, too. However, Groth specifies his assessment by saying that Low German is only older than High German in the sense that it has undergone fewer changes over the years and is thus closer to the "original" German:

[D]ie plattdeutsche Sprache ist die ältere, edlere der beiden Schwestern. [...] [̈̈]lter, das heißt nicht: früher entstanden, sondern weniger verändert, dem Urdeutsch näher. (7th letter, p. 87)

'Low German is the older, the more noble one of the two sisters. 'Older' does not mean created earlier but [simply] less changed, closer to the original German [Ur-German].'

As was common in the nineteenth century, biological metaphors were used to illustrate linguistic relationships. Groth claims equal status for Low and High German by arguing that both are trunks of the same tree, with further branches representing individual dialects:

12 As with many arguments presented in the Low German - High German discourse, this, too, has been well attested in earlier history, in particular in the purist debates of the seventeenth and eighteenth centuries (cf. Jones 1995). 
Der Baum deutscher Sprache besteht aus zwei Stämmen, einem hochdeutschen und einem plattdeutschen Sprachstamme, die beide wieder in eine Menge Zweige geteilt sind, und diese Zweige sind die Mundarten. (6th letter, p. 83)

'The tree of the German language consists of two trunks, a High German and a Low German one, each of which is divided up into many of branches, and these branches are the dialects.'

Thus importantly, the German language is seen as one tree with two equal trunks; Low German is not seen as either completely separate nor as a derivation of High German. ${ }^{13}$ There is some inconsistency in his argumentation. Whilst he claims Low German and High German to be equal, he is less clear as to whether there is a separate ethnic identity for Low German speakers. The following quotation appears to suggest that whilst Northerners are ethnic Germans - first and foremost -, they are also Low Germans, which seems to suggest that they are an ethnic sub-category of Germans:

Wir sind Plattdeutsche und wollen es bleiben, aber Deutsche sind wir vor allen Dingen. (10th letter, p. 93)

'We are Low Germans and wish to remain so, but first and foremost, we are Germans.'

Groth is at pains to emphasise that any attempt to preserve the language is not to be seen as a separatist movement and that it will not stand in the way of achieving German national unity:

Mit der politischen Einheit Deutschlands hat die Sprache gar nichts zu tun, diese Einheit wird durch ganz andere Mächte gestört oder erhalten. [...] Es ist demnach nichts zu befürchten, auch wir Plattdeutsche werden deutsch bleiben, selbst wenn wir unsere Sprache lieben und ehren und für ihre Erhaltung Sorge tragen. (12th letter, p. 96)

'The language has nothing to do with the political unification of Germany; this unity will be disturbed or maintained by very different forces. [...] There is thus nothing to be feared, we Low Germans, too, want to remain German, even though we love and cherish our language and are concerned about ensuring its survival.'

This last point relates to a more general debate in the Germany of the nineteenth century when commentators emphasised the need for a single national language in order to achieve ethnic and political unity (cf. Arendt 2010: 77ff.). Referring back to scholars such as Jacob Grimm, multilingualism was considered to be a threat to unity and hence eradicated - a sentiment known from France since the French revolution. For Groth, however, language was neither the only feature of national identity (Arendt 2010: 94) nor a particularly powerful one as such, and therefore he explicitly states that the revival of Low German would not harm the nationalist cause:

Oder ängstliche hochdeutsche Patrioten, welche fürchten, dass die deutsche Einheit, die da kommen soll, durch einige plattdeutsche Bücher verscheucht werde, da doch Millionen täglich Plattdeutsch sprechen? (5th letter, p. 82)

\footnotetext{
13 A slightly less neutral assessment of the relationship between these two linguistic sisters is given in the following quotation by Groth, however:

So schrieb Grimm in der Vorrede seiner Grammatik, Volksdialekte seien roh. [...] Wenn ich gegen einen solchen Ausspruch an, der sich namentlich auf das Plattdeutsche bezieht, kämpfend und Schritt für Schritt allmählich zu der Überzeugung, daß das Plattdeutsche die vollkommnere der beiden Schwestern sei, [...]. (1st letter, p. 70)

'Grimm said in his preface that dialects are rough. [...] In fighting such a statement, which appears to be aimed at Low German explicitly, I arrive, step by step, at the conclusion that Low German is the more perfect of the two sisters'
} 
'Or anxious High-German patriots, who fear that the impending German unity could be threatened by a few Low-German books, since millions actually speak Low German every day?'

In fact, rather than being a threat to High German, a thriving Low German could help replenish and keep alive the language, e.g. with its rich vocabulary from seafaring and life with and by the sea:

Das Plattdeutsche ergänzt also geradezu die Schriftsprache in dem großen Gebiete einer intensiven elementaren Anschauung, der Anschauung des Meeres mit all seinen Wechseln, Wundern und Gefahren [...]. (18th letter, p. 111)

'Thus Low German proves to complement the written language in areas of elementary understanding, the understanding of the sea with all its changes, wonders and perils.'

Were High German to be left to its own devices, its linguistic flexibility would soon ossify:

Wenn wir aber [...] die sinnliche Kraft der Schriftsprache untergehen lassen, so ist sie für immer dahin, und die Verknöcherung wird unwiderstehlich zunehmen. (19th letter, p. 115)

'Were we to let the emotional power of the written language disappear, it would be lost for ever and the ossification would increase unstoppably?'

This point relates to a more general assessment of the functional beauty of Low German, which is argued to contain much fewer hissing sounds or dead endings, i. e. non-morphemic word-final schwa, ${ }^{14}$ and hence boasts of greater clarity and brevity: ${ }^{15}$

Kürze und Wohllaut zeichnet das Plattdeutsche vor ihrer Schwester aus. [...] Die Zischlaute und die toten Endungen mit e sind wie Schnürleib und falsche Zähne dem Gesang der Schriftsprache unüberwindliche Hemmnisse. (16th letter, p. 104f.)

'Low German distinguishes itself from its sister by its brevity and euphony [...]. Hissing sounds and dead endings in $e$ provide insurmountable hindrances like a corset and false teeth to the harmony of the written language.'

Its linguistic status as a full language, rather than just an incomplete variety which lacks in sufficient vocabulary or range of expressions is demonstrated by its wealth of words for concrete things, it has, however, not exceeded its needs - as High German has - by inventing unnecessary words:

Gerade an konkreten Ausdrücken, am Holz, hat das Plattdeutsche Überfluß. Fähig ist es zu allem, wozu man eine Sprache braucht, nur gottlob noch nicht zu den Sprüngen und Hopsen, wozu man eine Sprache nicht mißbrauchen sollte, wozu man die hochdeutsche gezwungen, wodurch man ihre Glieder verrenkt und verbogen hat. [...] Dazu freilich ist das Plattdeutsche unfähig, aber nicht seine Schwäche macht es unfähig, sondern seine Gesundheit und Stärke. (9th letter, p. 92f.)

\footnotetext{
${ }^{14}$ Cf. also: "Das Plattdeutsche, ungehemmt durch Schrift und Druck, hat den natürlichen Prozeß der Auflösung vollendet und diese toten Silben meistens abgeworfen. Zum Beispiel: Die Briefe sind gekommen: ,de Brev sünd kam' [...]" (16th letter, p. 104)

'Low German, unhampered by writing or print, completed the natural process of dissolution and got rid of these dead syllables for the most past. An example: High German Die Briefe sind gekommen is Low German de Brew sünd kam'

15 The reference of beautiful sounds vs cacophony in comparing language has been used plentifully since at least the Baroque Age. In the Low German discourse we read that the anti-Low German professor Flörke (in 1825) complains about its monotonousness (Gleichtönigkeit) whilst his contemporary opponents praise its richness in sounds (Arendt 2010: 85).
} 
'Low German is abundant as regards terms for concrete things. It is capable of everything that one may need a language for; but luckily it has never been forced to engaged in the hopping and jumping, as High German has, which is an abuse of the language and which results in its twisting and breaking. [...] Low German is incapable of such things, it is not, however, its weaknesses that make it incapable, but its health and strength.'

Groth's poetry as well as its everyday usage shows how the deepest emotions can be expressed in Low German, and consequently, more advanced topics such as science and religion, too, can be discussed in this language, contrary to the views of many teachers, as shown further below:

Fähig ist die plattdeutsche Sprache zu allem - wie sollte sie nicht, die die tiefsten Töne der Menschenbrust in Liebe, Leid und Tod - nicht etwa im "Quickborn", sondern alle Tage ausspricht. [...] Fähig ist das Plattdeutsche zu allem, man kann sich über Wissenschaft und Religion darin unterhalten. (9th letter, p. 92)

'Low German is able to do anything - and how could be possibly different for a language which expresses the deepest emotions of love, passion, and death, not just in the Quickborn but on any day. [...] Low German is able to do anything, you can converse it in about science and religion.'

Groth is well aware of the threat of extinction the language is experiencing and he correctly identifies its lack of prestige as a major factor for this. Whilst in other regions of Germany, speakers happily use their dialects, he reports that North Germans are ashamed to use their local language because it is considered common and peasantlike. ${ }^{16}$

Jedes Volk lobt seine Muttersprache, und man verzeiht es ihm, bloß der Norddeutsche ließ sich bis dahin gefallen, seine Muttersprache als platt, d.h. hier 'gemein', zu bezeichnen und anzusehen. (1st letter, 70)

'Every people praises its mother tongue and is forgiven for doing so; only the North German allows his language to be referred to as 'flat', i. e. 'common'.'

In order to overcome the decline of the language, Groth appeals to the middle classes to lead the way by speaking only in Low German to their children, at least until they start school, and to farmers and country folk to only use High German with their children when talking about academic and scientific matters. ${ }^{17}$

Ihr Prediger, Lehrer und Beamten, Ihr Ärzte und Advokaten müßt vorangehen! Sprecht mit euren Kindern bis etwa nach Beginn der Schulzeit, also bis zum siebenten oder achten Jahre, nur plattdeutsch [...]. Ihr Bauern und Landleute, übt Euch meinetwegen mit Euren Kindern gelegentlich im Hochdeutschen, aber nur, wenn Ihr wissenschaftliche Dinge zu besprechen habt [...].(Erhaltung der Volkssprache, p. 154f.)

'You preachers, teachers and civil servants, doctors and lawyers must lead the way. Speak Low German with your children until just after they start school, that is until they are 7 or 8 . Farmers and country folk, speak High German with your children if you must, but only when you are discussing scientific things.'

\footnotetext{
16 This has been the case, of course, until very recently. Cf. also Arendt (2010: 81-5) for an account of Flörke's (1825) views on this, and Wienbarg (1834).

17 This encouragement to use Low German was not only aimed at the middle but also the higher classes and was picked up time and again from language lobbyists. This was a particular theme at the beginning of the so-called Niederdeutsche Bewegung in the late nineteenth and early twentieth century when poets like Gorch Fock passionately pleaded for the extension of Low German to domains of formal language use (cf. Langhanke 2010, 2011 for discussion; cf. Lesle 1990, Hopster/Wirrer 1994 to the history of the Niederdeutsche Bewegung).
} 
Importantly, it had never been his aim to replace High German as the language of serious writing and academic discourse; in fact, neither his poems and stories nor those written by his successors are about anything but literary topics. ${ }^{18}$ Low German is reserved for fictional writing; High German is not to be challenged as the language for official and non-fictional texts:

Wir wollen bloß untersuchen, wir wollen nichts umstürzen, wir wollen keine Gewaltsamkeiten. [...] Im Ernst, ich glaube, dass keiner der plattdeutschen Schriftsteller je den Gedanken gehabt, dasselbe im Gebiet des geistigen und geselligen Lebens wieder einzuführen, wo es nicht von selbst noch sich seinen Platz bewahrt hat oder ihn wieder erobern wird auch ohne sie.[...] Die Schriftsprache bot ihnen nicht, was sie suchten. [...] Dabei entstand im einzelnen das Bewußtsein der Macht und Schönheit unserer Muttersprache. (3rd letter, p. 74f.)

'We simply want to investigate, we do not want to upset anything, we do not want any violence. I seriously believe that none of the Low German authors have ever thought to introduce this language into the fields of intellectual and social life, where it did not already hold this place or would take it over without them anyway [...] The written language did not offer them what they were looking for. Thereby the awareness grew among some as to the power and beauty of our mother tongue.'

Sie wollen nicht plattdeutsch philosophieren, plattdeutsch dozieren, plattdeutsche Kompendien, Konversationslexika, literarisch-kritische Journale schreiben. [...] Aber ihren Platz wollen sie haben, und sie haben ein Recht dazu. (9th letter, p. 90)

'They do not want to philosophise in Low German or lecture in Low German, nor do they want to write Low German compendia, encyclopedias, or literary journals. But they do want to retain their place and they have the right to do so.'

These quotations testify to Klaus Groth's detailed thinking on how to promote his native tongue. He recognized that simply publishing poetry will not enhance the status of Low German as a serious language, suitable for all linguistic discourses. His views became prominent during the second half of the nineteenth century but as we will see below, a general endorsement of Low German as a cultural treasure of Northern Germany did not necessarily result in its promotion or re-awakening as a language to be used in writing or schooling. In what follows, we will investigate the views of language practitioners, i. e. school teachers in elementary schools, whose tasks largely consisted of providing very basic schooling to the rural population. The language of schooling had been exclusively High German for the previous two or three centuries. We cannot always be entirely sure in what language lessons were conducted in elementary schools (Volksschulen). The native language of the children will have been almost exclusively Low German ${ }^{19}$ and we have some indirect evidence that not all classes were held entirely in High German, ${ }^{20}$ yet the only officially permitted language was High German. Groth felt strongly that Low German writings should find its way into schools, albeit not as a language of instruction, as it was a scandal to neglect the pupils' mother tongue in their education:

Es scheint bald dahin zu kommen, daß wir wieder von einer plattdeutschen Literatur sprechen dürfen. Die Pädagogik ist schon aufmerksam geworden, mehr und mehr Stimmen erheben sich gegen die unverantwortliche Vernachlässigung der eigentlichen Muttersprache in den Schulen,

\footnotetext{
18 There is a certain chicken-and-egg situation in that Low German, like many other non-standard varieties, is seen to be a 'warm' language only suitable for literary and pleasant topics, whilst the fact that only such topics are used in Low German writing confirms the stereotype that nothing else would be suitable.

${ }^{19}$ Or, depending on location, one of the other two non-dominating languages South Jutish and Frisian.

${ }^{20} \mathrm{Cf}$. Scheuermann 2004 and Langer 2011.
} 
eine plattdeutsche Fibel, Grammatiken, plattdeutsche Volksbücher und Volkskalender sind gedruckt. (24th letter, p. 129)

'It seems that the time will soon come when we can once again talk of a Low German literature. Educationalists have already become aware of this. More and more voices speak out against the irresponsible neglect of one's actual mother tongue in schools. A Low German primer, grammar, Low German books and a calendar have been printed.'

and he takes pride in the fact that due to his influence, textbooks and other materials have started to include Low German passages (Groth 1889/99: 56):

Ich erreichte es, daß auf Lehrerkonferenzen und in Schulzeitungen lebhaft für und wider die Beibehaltung der Mundart in dem Schul-, namentlich in dem Sprachunterricht gestritten wurde, daß Lesebücher Plattdeutsch aufnahmen, Anweisungen zur Benutzung der Mundart für den Sprachunterricht zum Beispiel von Dücker und anderen erschienen und benutzt wurden, vor allen Dingen, daß die systematische Verfolgung des Plattdeutschen bei der Landjugend in den Schulen und ein gewisser Respekt für die Volkssprache wieder eintrat. (Wie mein Quickborn entstand, p. 56)

'Because of me, the pros and cons with regard the retention of the dialect in school and specifically in language lessons has been vividly debated at teacher conferences and in education journals; primers have incorporated Low German, instructions on the usage of the dialect for language teaching for example by Dücker and others have appeared and have been used; above all the systematic monitoring of Low German among the rural youth in schools and a certain respect for the common language has once again risen.'

We see here how Groth takes an active interest in the role of schooling for the promotion and survival of Low German. In the second part of this article, we will discuss the views of teachers on the suitability of Low German in schools and compare their positions to Groth's arguments. To limit our material, we will focus on a data set from 1863-1870, i. e. the period directly after the end of the Danification of Schleswig-Holstein and shortly after the publication of Groth's letters. He had been established as an important poet by then, with his Quickborn selling well in its eighth edition. The restoration of Low German as a literary language, albeit still vastly less important than High German, continued to thrive, with new authors, such as Fritz Reuter (1810-1874), emerging and being successful.

\section{The Schleswig-Holsteinische Schulzeitung}

The data for this sections were extracted from the Schleswig Holsteinische Schulzeitung (henceforth SHSZ), the weekly publication of the Schleswig-Holstein association of school teachers working in elementary schools (Volksschulen), as opposed to Latin schools (Gelehrtenschulen). Every issue, some 8-12 pages long, contained job advertisements, reports from conferences and local associations, and one or two larger essays on particular topics related to pedagogy, laws and government decrees, or teachers' pension rights. Political topics were not excluded: A particularly passionate debate after 1863, with the end of the "Danish period", concerned the teachers' demand for a new school textbook which was to be free from Danish influences and which merited the description of a vaterländisches Lesebuch ("a patriotic text book"; cf. Langer 2012 for an account of this debate). For our purposes, the most interesting articles relate to the teaching of language and grammar (Sprachunterricht) as well as discussions on the whether or how to integrate the local dialect into lessons. A surprisingly difficult task is to establish how school lessons were actually conducted, in particular with regard to the choice of language used. Some of the most valuable sources are school inspection reports (cf. Hansen 1991; Langer 2011; Scheuermann 2004) and accounts in private memoirs and anecdotal evidence: 
In den Schulen blieb sie [= Low German] bis in die neuere Zeit hinein, und viele meiner älteren Collegen werden, wie ich, in ihrer Jugend von einem plattdeutschen Lehrer unterrichtet worden sein, wenn überhaupt von einem Unterrichten dabei geredet werden kann. (SHSZ ${ }^{21}$, No 4, 26.1.1865, p. 15)

'In schools Low German lasted until the modern period and many of my older colleagues will have been taught by a Low German teacher in their youth, as I was, if one can even talk of proper teaching at all.'

Teaching the mother tongue - and we deliberately do not specify which type of German is meant here - was considered to be a particularly important task of teachers, some even argued that it was the foremost and most important task of schooling:

Um nur Eins zu nennen, was die Volksschule doch vor allem zu cultiviren hat, die Muttersprache, welche Resultate, was Methodik derselben anbetrifft, haben wir aufzuweisen? [...] Besitzen unsere Schüler jetzt eine größere sprachliche Gewandtheit und ist das Volk jetzt der Sprache und Rede mächtiger, als vor 10 Jahren? [...] Wie wenig hat die Schule bis jetzt noch ihre erste und wichtigste nationale Aufgabe gelöst? [...] Als deutsche Volksschule und deutsche Lehrer haben wir die Aufgabe, das deutsche Volk zur Gewandtheit seiner Muttersprache zu befähigen und ihm den Sinn derselben aufzuschließen - lassen wir das als Ideal stehen. (No 3, 21.1.1869)

'To name just one thing that the elementary school above all has to cultivate - it is the mother tongue. What results with regard to methodology are we able to show? Do our pupils possess a greater fluency now and are the people more powerful with regard language and speech now than they were 10 years ago? How little has the school solved its first and most important national task? As German elementary schools and German teachers we have the task of enabling the German people to become fluent in their mother tongue and to unlock the meaning of it - that should remain the primary goal.'

The key term here is Muttersprache ('mother tongue') which in most articles is understood to simply be German ${ }^{22}$, i.e. neither Low German nor High German. This understanding of mother tongue chimes with Groth's "one tree - two trunks" metaphor mentioned above, in that it sees Low German as sister of High German, i. e. both varieties, or even languages are of equal standing in relation to the more general entity of German. ${ }^{23}$ Similarly, we find a number of correspondences between the assessments and definitions offered by Groth and those presented in the Schulzeitung-articles. This is not necessarily to suggest that the one was influenced by the other, though on occasion, explicit reference to Groth's (and other famous writers) can be found in the SHSZ.

In the late $1860 \mathrm{~s}$, a passionate debate ensued between an anonymous writer who declared himself to be from outside the teaching profession and used the pseudonym Nicht-Pädagoge (non-pedagogue $)^{24}$ and a number of school teachers who responded to his challenges. The Nicht-Pädagoge argued in several contributions that teachers in particular could be a mighty force $^{25}$ in the debate on the restoration of Low German as a reputable, proper language and

${ }^{21}$ All quotations in this section will be from the SHSZ unless stated otherwise.

${ }^{22}$ It is worth pointing out that individual authors are by no means consistent in this respect. The terms mother tongue, dialect (Mundart), common language (Volkssprache) and language are applied differently and inconsistently to the terms Low German, High German, and German.

${ }^{23}$ The nomenclature is not used consistently. As we saw about in Groth's first letter, he sometimes refer to Low German, rather than just German more generally, as the mother tongue of North Germans.

${ }^{24}$ There is no hint as to the true identity of this writer.

${ }^{25}$ Die Lehrerwelt ist eine Macht."The profession of teachers is a real force." (italics in the original; No 14, 2.4.1868, p. 53ff.) 
were thus called upon to work in this direction. His opponents, too, were good Germanminded Schleswig-Holsteiners and often agreed with him in the basic assumptions, e. g. that Low German was the natural, indigenous, and historic language of the North German tribe, which revealed the people's feelings and world in a unique way. The teachers Tiessen and Schmarje were amongst the most vocal in this debate and their contributions feature prominently in our account:

Die Volkssprache - und also auch die plattdeutsche Mundart - ist nicht etwas Angelerntes, willkührlich Gemachtes, sondern sie ist aus dem Volksgeiste naturgemäß heraus geboren; sie ist nicht stabil, sondern stets sich fortentwickelnd. (No 52, 26.12.1864, p. 212; Tiessen)

'The common language - that is the Low German dialect - is not something that one learns, not something deliberately created, but something which originates naturally from the people's spirit; it is not stable but always continuously developing.'

Die plattdeutsche Mundart ist die Umgangssprache des Norddeutschen. Sie ist erwachsen auf dem Boden des Volksstammes, der die norddeutsche Tiefebene bewohnt und das Product einer Jahrhundertlangen [sic!], an mannichfachen Kämpfen reichen Vergangenheit. Sie ist die Muttersprache $^{26}$, in welcher schon unsere Vorväter sich als stammverwandte Brüder begrüßten, in welcher sie sich gegenseitig verstanden und ihre geschäftlichen Beziehungen vermittelten und in welcher sie ihren heiligsten Herzensangelegenheiten einen Ausdruck gaben. [... S]o ist in der plattdeutschen Sprache auch die Volksgeschichte des Niederdeutschen ausgeprägt. Eben deshalb ist sie mit dem Volke verschmolzen, ganz zu seinem Bildungsstandpunkt passend, ganz seine Gemüthswelt offenbarend, ganz sein geistiges Eigenthum geworden. (No 52, 26.12.1864, p. 212f.; Tiessen)

'The Low German dialect is the colloquial language of the north German. It developed on the ground of the indigenous people that inhabited the north German plains and is the product of a century-long history, rich with battles. It is the mother tongue in which our forefathers as kindred brothers greeted one another, in which they understood each other and carried out their business transactions and in which they expressed their most sacred affairs of the heart. Therefore the history of the Low German people is also reflected in the Low German language. For exactly this reason the language is merged with the people, perfectly in keeping with its educational standpoint, perfectly revealing of its spiritual world, it has perfectly become its own intellectual property.'

However, whilst Low German is the language of the Northerners, High German (note: not German!) is the common language of all Germans:

Aber während die plattdeutsche Sprache das Eigenthum eines Volkstammes ist, so ist die hochdeutsche Sprache ein Gemeingut eines ganzen Volkes, in welcher alle nationalen Stämme, mögen sie hausen in den Tiefebenen des Nordens oder in den bergumschlungenen Thälern des Südens, sich vereinen. (ibid.)

'But while the Low German language belongs to an indigenous group, the High German language belongs to a whole nation, in which all national tribes unite, whether they live in the lowlands of the north or in the mountain surrounded valleys of the south.'

High German was the tool for national unification and is the language in which the national literature is written and it is for this reason that it stands higher and commands greater power and impression than Low German (ibid.).

\footnotetext{
${ }^{26}$ Note here how Tiessen refers to Low German as a Mundart, Umgangssprache, Muttersprache, and Sprache (and cf. footnote 19 in this context).
} 
In contrast to the very critical debates in the first half of the century mentioned in section 2 of this article, none of the commentators in the Schulzeitung openly attacks Low German as inferior or not worthy of consideration. Instead, even those who argue most vocally against its usage in school declare themselves to be great friends and admirers of the language. But, they argue, it should remain what it is, a language for spoken and informal discourse, to be used in the streets or with family:

[Ich bin] ein großer Freund und Verehrer des Plattdeutschen, und würde es daher als ein Unglück, als einen intellectuellen und moralischen Rückschritt ansehen, wenn, wie Einige wollen, Andere befürchten, es dahin kommen sollte, daß auf der Gasse und in dem trauten Familienkreise statt seiner die hochdeutsche Sprache Aufnahme fände, Bürgerrecht bekäme. (No 10, 5.3.1868, p. 37, Schmarje)

'I am a good friend and admirer of low German and would therefore think it a misfortune, an intellectual and moral regression, if, as some want and others fear, it should come to the point where on the street and in the trusted family-circle High German instead of Low German would be used and would be a civil right.'

Ich liebe die plattdeutsche Sprache, aber ich habe mich nie für den Schulgebrauch derselben begeistern können. Sie gehört auf den Markt des Lebens, in die Conversationszimmer zur gemüthlichen Unterhaltung, nicht in die Schule, nicht auf die Kanzel. (No 52, 26.12.1864, p. 212, Tiessen)

'I love the Low German language but I have never been able to encourage the use of this language in schools. It belongs on the market of life, to the drawing rooms, used in cozy conversation, not in the school, not on the pulpit.'

The discussion of the place of Low German in schools can be divided into two parts, relating to the practical side of providing schooling in the actual native language of the children, on the one hand, and to the more cultural-educational side of recognising Low German and its literature as important cultural treasures which the children ought to acknowledge and become aware of. The latter point already hints at the increasing withdrawal of Low German from everyday life as we witness it today. As regards the former point, advocates of Low German never suggested that the language ought to replace High German; however, in order to ease the children's entry into schools, teacher should make use of the children's mother tongue. These contributions were often embedded in more general discussions of modern pedagogical methods to reform elementary schooling (e.g. Pestalozzi). In particular, it was felt that schools need to use the pre-school education provided in the home and build on rather than ignore or reject what children have learnt at home:

[D]ie Schule [muss sich] zur Erreichung ihres Zweckes auch der Mittel bedienen, mit denen die Entwicklung des Kindes beginnt, die ihm heimlich und vertraut sind, und an sein Herz sprechen: es тиß mit einem Worte in der Schule die Sprache wiederfinden, mit welcher die Mutter zu ihm spricht, und in welcher es bisher die Welt seiner Umgebung kennen und benennen gelernt hat. (No 13, 26.3.1868, p. 49)

'In order to achieve its purpose, schooling have to use the means with which the development of the child begins, which are homely and familiar for him and speak to his heart: in other words, at school the child needs to be able to find the language in with which the mother speaks to and with which he has got to know and name his surroundings.'

It is argued that it is much less important to worry about minor linguistic problems which arise when using a Low German pronunciation as long as the children grasp the concepts of 
what they are taught. In fact, teachers should use the dialect themselves when addressing children in order to create a bond of trust with the pupils:

Es ist anfangs sehr gleichgültig, ob das Kind Hus oder Haus, Stol oder Stuhl sage; genug wenn es weiß, was mit den Benennungen bezeichnet wird. So ist die Auffassung der Sache immer das Wesentliche und der Hauptzweck des Schulunterrichtes; Dieses ist aber ein untergeordnetes und gleichwohl genugsam erreichbares Ziel der Schule, das Kind in die Formen der hochdeutschen Sprache einzuführen, indem Belehrung und Erkenntniß nicht nur nicht an dieses Mittel gebunden sind, sondern häufig dadurch Abbruch leiden. Denn das Kind wird nur dann in der Schule sich durch häusliche Anmuth und Freundlichkeit angesprochen finden, wenn der Lehrer in der Mundart des Volkes zu ihm spricht. (ibid., p. 49f.)

'In the beginning, it doesn't matter whether the child says [LG] Hus or [HG] Haus, [LG] Stol or [HG] Stuhl, as long as he knows what the terms refer to. The understanding of the substance is always the core and central purpose of schooling. But to instruct the child in the forms of High German is a subordinated, even if equally achievable, aim: frequently enough this doesn't result in elucidation and understanding but their breakdown. The child will only respond properly to a welcoming and homely environment at school if the teacher speaks in the dialect of the people to him.'

In those schools where the dialect has been completely banned and where only High German is used, pupils lose their lightheartedness, wit, and sense of humour.

Mit der Verbannung der Mundart aus der Schule ist auch herzliche Munterkeit, Scherz und Witz verbannt. (italics in the original; ibid., p. 51)

'By banning the dialect from the school, any warmth, friendliness, and jest is also banned.'

Opponents of this view argue that it is precisely the duty of the school to eradicate this use of Low German as soon as possible and to train pupils in the language of German high culture:

Unsere Muttersprache hat mit der plattdeutschen Sprache sich nur insofern zu befassen, als die Kinder selbige in die Schule mitbringen. An selbige anknüpfend hat sie die Kinder thunlichst bald zu der einzigen, den Kindern von Haus aus mehr oder weniger auch bekannten deutschen Cultursprache, der hochdeutschen, hinüberzuführen. (No 34, 20.8.1868, p. 137f.)

'Our mother tongue need only deal with Low German to the extent that the children bring the latter to school. It is the school's task to transfer the children as quickly as possible to the only language of culture, High German, which should be familiar to the children already to some extent.'

It may be tempting and practical to ease pupils into the monolingual nature of schools by permitting the use of Low German in the first few days but, step by step, it is argued, High German has to take over:

Wenn das Kind die Schule erst betritt und mit seiner ganzen Gedankenwelt noch auf dem Spielplatz weilt, möchte es gerathen sein, in seiner Sprache, wofür es einen correspondirenden Inhalt hat, mit ihm zu conversiren. Aber sobald der Unterricht eintritt, muß es auch nach und nach mit der Erweiterung des Unterrichts stufenmäßig in die hochdeutsche Sprache eingeführt werden. (No 52, 26.12.1864, p. 212)

'When the child first goes to school and waits in the playground, still lost in his familiar thoughts, it would be advisable to converse with him in his language, for which he has all the right words. But as soon as he enters a lesson, High German must be introduced step-by-step along with the broadening of the teaching.' 
Some commentators agree that there may be a use for Low German as a means to illustrate and exemplify particular points in class but these instances ought to be reserved for language, and in particular grammar classes:

Soll denn das Plattdeutsch im Unterricht gar nicht gebraucht werden? Warum nicht? Im eigentlichen Unterricht, wo man über die Sprache reflectirt, mag es zur richtigen Auffassung und Würdigung der Sprache ganz recht sein, wenn die Formen und der Geist des Plattdeutschen angeschaut und mit dem Hochdeutschen verglichen werden. (ibid.)

Summa: Die hochdeutsche Sprache ist die Sprache des Gesamtunterrichts und mit der zunehmenden Bildung durch den Unterricht soll auch der Reichtum der hochdeutschen Sprache bei dem Kinde naturgemäß zunehmen (ibid.)

'Should Low German not be used at all in the classroom then? Why not? In lessons where one is reflecting on language it may be completely appropriate to look at and compare the forms and spirit of Low German with High German in order to gain a proper understanding and appreciation of the language.'

'All in all: High German is the language of general schooling and with the increasing literacy in schooling the richness of the High German language should naturally increase among the children.'

Low German may continue to be used in the home or with less 'cultured' topics, in other words, these opponents of the use of Low German in schools do not argue for the extinction of the language, in stark contrast to views expressed half a century earlier, as shown above. Such domain-specific division of the use of Low and High German can also be found in Groth's ideas mentioned above. But whilst Groth desires stability for the use of Low German, the teachers in the SHSZ see it much more as a passing phenomenon, undergoing a transitional phase:

Unser Volk soll für's tägliche Leben, wenn von Kohl und Kuh die Rede ist, die plattdeutsche Sprache gerne und ohne Hohn behalten, so lange es will; es wird so gar lange nicht wollen. Es würde aber die Schule zur Rechenschaft ziehen, wenn sie durch Plattdeutsch die hochdeutsche Sprache schädige. (No 34, 20.8.1868, p. 137f.)

'Our people should gladly and compliantly keep the Low German language for daily life as long as it wants, when the topics are cabbage and cows; it will not want to for very long anyway. But it hold the school accountable if it damages the High German language through Low German usage.'

It is generally agreed by the opponents that Low German is linguistically unsuitable for the expression of abstract and technical concepts and thus a conversation about scientific or academic subjects would simply not be possible. Low German is not a language for science (Wissenschaft):

Aber ein Buch, dessen Zweck Belehrung ist, würde sich schlecht empfehlen, wenn es in plattdeutscher Sprache unsere Begriffs= und Ideenwelt veredeln wollte. (No 52, 26.12.1864, p. 212)

Wissenschaft und hochdeutsche Sprache [gehen] Hand in Hand zur Erlösung der Nation, und somit wären wir auch zu dem Punkt gelangt, wo die hochdeutsche Sprache ihr Recht hat und wo sie allein herrschen soll, denn beide, sowohl die plattdeutsche, als die hochdeutsche Sprache haben ihre Berechtigung, aber jede auf ihrem Gebiet. (ibid.)

'But a book whose purpose is instruction would not be recommendable, if it was intended to refine our concepts and ideas of the world in Low German.' 
'Science and High German go hand in hand for the salvation of the nation and so we could reach the point where the High German language has the right, where it should reign solely because both languages, High and Low German have their authority but each in their own area.'

An exception to the exclusion of Low German from schooling pertains to literary texts. During the nineteenth century, Romantic notions of the interrelationship between ethnicity, culture, origin and language abounded and, as we saw above, poets like Klaus Groth successfully stimulated these sentiments into the production of original poetry and literature. The school teachers contributing to the SHSZ were proud and patriotic Schleswig-Holsteiners for whom the Low German language represented an important cultural asset. Whilst efforts to introduce the language into schooling proper - as a response to the fact that the children tended to be monolingual Low German speakers when starting school - were rejected by teachers across the board, there was equal agreement that reading and rehearsing good literature in Low German would be quite beneficial. There was no objection to Groth's and Reuter's literary efforts as such:

Klaus Groth, wenn er die Denkweise und das Alltagsleben seines Volksstammes schildern will, mag ganz recht thun, wenn er seine Schilderungen im plattdeutschen Idiom giebt; Fritz Reuter, wenn er von dem Alltagsleben des Mecklenburgers, wie von seinem Charakter und seiner Moral ein Bild uns vorführen will, spricht er zu uns in dem Platt des Mecklenburgers. (No 52, 26.12.1864, p. 212)

'When Klaus Groth aims to portray the mindset and everyday life of his people, he can do this best when he gives his portrayals in the Low German dialect; when Fritz Reuter wishes to present a picture of the everyday life of the Mecklenburgers or of his character and morals, he speaks to us in the Mecklenburger dialect.'

Groth and Reuter are usually the only two authors mentioned in arguments in favour of reading Low German literature (cf. Langhanke 2011: 92-106) in schools and their work is often described as of good quality and eminently suitable for school education:

[D]as Hochdeutsche [ist] die Sprache der Schule und der Literatur, [aber es] giebt [...] doch, seit Klaus Groth uns seinen Quickborn gegeben, auch eine plattdeutsche Literatur, und zwar für das Volk und für die Volksschule auch, und der Schule Aufgabe ist es, das Volk auch in diese Literatur einzuführen, es in derselben heimisch zu machen. [...] Durch eine solche [...] Literatur führen wir die Schüler nicht nur ein in den Bau und Geist auch der plattdeutschen Sprache, sondern wir tragen dadurch, mehr als durch die Ertheilung eines abstracten grammatikalischen Unterrichts geschehen kann, zur sprachlichen Ausbildung derselben überhaupt bei [...]. ( No 10, 5.3.1868, p. 37)

'High German is the language of school and literature but since Klaus Groth gave us his Quickborn, there is also a Low German literature, aimed at the people and elementary school, and it is the task of schools to familiarize the people with this literature. [...] Through such a literature, we familiarize the pupils not just with the grammar and spirit of Low German, but we also achieve much more for their linguistic education than by teaching abstract grammar lessons.'

The final set of arguments expressed in the SHSZ relates to the future prospects of the language. The Nicht-Pädagoge, as the most vocal of the 'Low German into schools'-lobby, expressed the fear that, without the proper protection of Low German, the linguistic landscape would not result in a continued diglossia of Low German and High German but rather that Low German would turn into a corrupted version, a patois - a term also used by Groth in this 
context (6th letter, 1858: 84) or Missingsch/Messingsch (cf. Langhanke 2011: 97). This, he argued, can already be witnessed in Berlin, a (formerly) Low German city: ${ }^{27}$

Berlin ist eine plattdeutsche Stadt und hat das Plattdeutsch verlernt. Und was unser Schicksal sein wird, kann uns eben Berlin zeigen: wir bekommen dann einen dem Berlinischen ähnlichen Dialect wieder und das mit Nothwendigkeit, denn das Volk bedarf zwei Sprachen. (No 14, 2.4.1868, p. 53, NP)

'Berlin is a Low German town but has forgotten how to speak Low German. And Berlin can show us how our future may turn out: we will acquire a dialect similar to Berlinisch and necessarily so because the people need two languages.'

Where teachers simply refuse to use the native language of the pupils, the quality of Low German will decline:

Es ersteht mit dem Verfall des Plattdeutschen der Schule und den Lehrern und dem Lernen auf der Stelle erst ein Feind und ein wahrhaft widerlicher, viel schwerer und nieder zu kämpfender wirklicher Feind. Die plattdeutsche Sprache ist kein Feind der hochdeutschen Sprache, wie zwei Sprachen nie einander Feind sein können. Das Patois aber, das Messingsch ist es. (ibid.)

'With the decline of Low German an enemy arises against the school, the teachers and learning in general, a truly disgusting enemy, a much tougher and real enemy who will be hard to defeat. Low German is no enemy of the High German language, however, just as two languages can never be enemies of one another. A patois, however, a Messingsch is able to be an enemy.'

This view, proposed by the Nicht-Pädaoge, was rejected by members of the teachers' faction, who argued that Low German had not been used in schooling for decades and still continued to thrive as a spoken language. Low German speakers had imbibed the language with their mother's milk and grown up to be conservative people who did not easily change their habits, including their linguistic ones. The language would not disappear even if it was not included in the schools' curricula:

Aber das befürchte ich ganz und gar nicht, und obgleich von gewisser Seite her alle Anstrengungen gemacht werden, einen solchen Wechsel herbeizuführen, und obgleich $D r$. $\mathrm{Harms}^{28}$ schon zu Anfange der vierziger Jahre seiner "lewen Landessprak en gode Nach" gesagt hat, so kann ich doch nicht daran glauben, daß diese Sprache jemals in die Lage kommen wird, ihren Schwanensang singen zu müssen. [...] Die plattdeutsche Sprache wird in unsern Herzogthümern nicht aussterben, wenn auch die Schule dieselbe als Unterrichtsgegenstand in ihren Lectionsplan nicht aufnimmt. (No 10, 5.3.1868, p. 37f., Schmarje)

But I do not fear that at all and although from certain sides every attempt is being made to bring about such a change and although Dr. Harms already said a "good night to our country's language" in the 1840s I cannot believe that this language would ever be in the position of having to say its last hurrah. The Low German language will not die out in our Duchies, even if the schools were not introduce it as a subject in their curriculum.

This optimistic view that Low German would survive independently of whether it was actively protected or supported was no longer shared by Groth. In his 1878 publication, some

27 Incidentally Groth expressed remarkably similar views on the corrupting changes in urban vernaculars in Berlin and other North German cities (1865/6: 153, also his 6th letter (1858: 84)). He blames this existence of a Greuelhochdeutsch ("horrific High German") on a lack of respect for and a neglect of Low German, the native language of these places (cf. also Langhanke 2011: 90).

28 Claus Harms (1778-1855) was an important theologian and vicar in Kiel and an influential, if critical, proponent of Low German. He was the author of a school textbook Gnomon, ein Volks- und Schullesebuch (1843) and wrote the preface for the first edition of Groth's Quickborn. 
20 years of his open letters, he appears to have given up on the fight for the retention of Low German as a spoken language. However he felt that as long as there is a body of good-quality literature in Low German, be it historical texts or modern productions, a loss of active spoken usage of the language can be compensated for. Scholars and philologists will continue to study and learn the language and thus secure its place in culture and history:

\begin{abstract}
Aber selbst wenn die Liebhaber plattdeutscher Dichtung mit der Zeit aussterben, wenn das lebendige Verständniß der Sprache aufhören sollte, so werden die Höchstgebildeten germanischen Stammes im gelehrten Studium zurückgreifen, wieder lernen müssen auf Universitäten und Hochschulen, was Ihre Vorfahren gesprochen und gedichtet, so gut und noch mehr wie man jetzt Altdeutsch treibt und lernt. (Groth 1878. Vorwort, V)
\end{abstract}

'But even when the lovers of Low German poetry die out over time, when the living understanding of the language would also stop, so will the most highly educated Germanic peoples in scholarly study go back to Low German, they will have to learn it again at universities and high schools, the language which their forefathers had spoken and written, as well and even more so than one learns old German.'

In this way, Groth's views chime with those of the teachers who thought it sufficient to secure the place of Low German in schools in the form of reading and reciting literary works, rather than as a living language.

\title{
5 Conclusion
}

The comparison of Groth's arguments with those put forward by contemporary school teachers permits us to arrive at valuable insights into the perception of Low German in the nineteenth century, in particular with regard to its place in elementary schools.

The bilingualism prevalent amongst the German speakers in Schleswig-Holstein, with Low German as the low variety and native language of most people and High German as the high variety and the language of official discourse, including schooling, church services and administration, continued from previous centuries. In the first half of the nineteenth century, isolated but vocal commentators argued strongly for the abolition of Low German as it prevented its speakers from rising above their station. Low German was reported to be a peasants' language, ill-suited for formal and higher-register use, and thus an obstruction to achieving social cohesion amongst the people. Whilst even before 1850 some voices rejected these views, Klaus Groth's publications demonstrated that Low German was a suitable vehicle for good-quality poetry and hence a language in its own right. He successfully reevaluated Low German as a national treasure worthy of protection, as shown in this article. A result of this re-evaluation was the inclusion of Low German poetry, much of it by Groth, and short reading passages in school textbooks during the nineteenth century, a tradition which continues today. Whilst literary examples of contemporary Low German were deemed worthy of study in school, his more general plea to afford Low German more generally a much greater space in school lessons, i. e. also as a spoken language, was not followed by school teachers. ${ }^{29}$ As shown in this article, they argued with a certain degree of discomfort: on the one hand they acknowledged Low German to be of great cultural value for the identity of Northerners, which carried great emotional associations and historical heritage; on the other hand, however, they argued that school was a place of scholarly instruction and that Low German was unsuitable for academic disciplines (Wissenschaft). It was felt that abstract and technical concepts could simply not be expressed in Low German. The most crucial argument, however, appears to have been that only High German was the language of German

${ }^{29}$ Groth's writings were clearly well-known amongst school teachers and he himself contributed articles to the Schulzeitung, albeit not - to our knowledge - on the topic of Low German in schools. 
national unity and no other language should be challenging this. Promoting Low German was thus seen not just as a drive towards cherishing Northern culture but also as an - at least implicitly - separatist argument against all-German unity, and therefore Low German was unsuitable for a united Germany. As Petersen summarises in the SHSZ: After the long fight for German nationality and nationhood, the Schleswig-Holstein people now demanded for their schools the exclusive use of the German national language, namely High German:

Das schleswig=holsteinische Volk hat bis auf's Blut gekämpft für deutsche Nationalität; hat in anderthalbe Decennien unter schrecklichem Druck seine deutsche Nationalität bewahrt; gehört jetzt auch politisch zu Deutschland: Es verlangt jetzt mit Recht für seine Schule ausschließlich die hochdeutsche Sprache. (116, No 34, 20.8.1868, S. 137f. (Petersen))

'The people of Schleswig-Holstein have fought to the death for German nationality, have kept their German nationality for one and a half decades under terrible pressure; and now belong politically to Germany. Therefore they quite reasonably demand the exclusive use of High German in their schools.'

We thus see that Groth's writings are likely to have had a direct effect on the dying down of arguments for the active extermination of Low German. His original poetry in Low German commanded great respect amongst teachers, and most happily agreed that such works ought to form part of school lessons, so that, consequently, school textbooks published after 1850 often contain literary works in Low German - mostly taken from Groth's Quickborn. However, such support remains largely restricted to a recognition amongst teachers that Low German forms an important part of North German culture. Arguments for permitting the use of Low German as a language of instruction in lessons in order to facilitate the children's learning are rarely presented and never gain real support. We thus see how the creation of literary works in Low German has succeeded in raising the language's sociolinguistic profile sufficiently to make it acceptable as an item of North German (high) culture. However, its stigma as a rural or lowerclass language, and the existence of a widely - nationally! - accepted other language, High German, prevented it from truly regaining its status as an accepted spoken language or a language for non-cultural writing, i. e. administration or school lesson. This division between the status of Low German as acceptable in Northern literary culture, on the one hand, and as virtually completely unacceptable in any other linguistic domain continues until today.

The discussions in the SHSZ show that the sociolinguistic situation in Schleswig-Holstein presented a peculiar case. Rather than reject any non-standard language in favour of High German, as presumably happened elsewhere in Germany, the peculiar and generally accepted status of Low German as a language rather than a dialect posed a real problem. On the one hand, it was an important part of Northern identity, culture, and history, whilst, on the other hand, it was an obstacle to national unity which was 'conducted' in High German only. Most importantly, however, Low German as a living language had already lost far too much ground over the previous centuries in order to regain important linguistic domains such as "formal writing", etc. Any attempt to extend the language's use had to fail because of the overwhelming presence of High German in written and formal discourse.

To the modern reader, the range and type of arguments will be familiar. Many minority and regional languages today are engaged in similar debates on their linguistic validity, the appropriate discourses in which they can be used, their nationalizing or ethnic status, and their ability to express complex thoughts. This holds for the modern non-dominant languages of Frisian, South Jutish, and Low German in the German-Danish border region, too, and, as this article has shown, the arguments heard today are based on a long tradition of similar thinking. 


\section{References}

\section{Primary Sources}

Dähnert, Johann C. (1781/2011): Plattdeutsches Wörterbuch nach der alten und neuen pommerschen und rügischen Mundart. Vaduz: Sändig.

Groth, Klaus (1858/1981): "Briefe über Hochdeutsch und Plattdeutsch." In: ders. (1981): Sämtliche Werke. Bd.6: Über Sprache u. Dichtung. Kritische Schriften. Hrsg. Von Ivo Braak u. Richard Mehlem. Heide, Boyens: 67-137.

Groth, Klaus (1878): "Vorwort. Franz Giese: Frans Essink. Sin Leben un Driben as olt Münstersch Kind. 3rd ed. with a preface by Klaus Groth. Braunschweig: Harald Bruhn.

Groth, Klaus. (1889/1899/1981): "Wie mein Quickborn entstand." In: ders. (1981): Sämtliche Werke. Bd.6: Über Sprache u. Dichtung. Kritische Schriften. Hrsg. Von Ivo Braak u. Richard Mehlem. Heide, Boyens: 35-65.

Groth, Klaus (1865-1866/1981): "Erhaltung der Volkssprache." In: ders. (1981): Sämtliche Werke. Bd.6: Über Sprache u. Dichtung. Kritische Schriften. Hrsg. Von Ivo Braak u. Richard Mehlem. Heide, Boyens: 139-173.

Flörke, Gustav Heinrich (1825): Ueber die Unvollkommenheit der plattdeutschen Sprache [...]. In Freimüthiges Abendblatt. Volumes 07/321 and 322. Schwerin: J. C. H. Bärensprung.

Humboldt, Wilhelm von (1836): Über die Verschiedenheit des menschlichen Sprachbaues. Berlin: Königliche Akademie der Wissenschaften.

Raupach, Bernhard (1704/1984): Von unbilliger Verachtung der Plat-teutschen Sprache. edited by Wolfgang Lindow and reprinted with a translation from the Latin. Leer: Schuster.

Richey, Michael (1755): Idioticon Hamburgense oder Wörter-Buch zur Erklärung der eigenen, in und um Hamburg gebräuchlichen Nieder-Sächsischen Mund-Art. Hamburg: Conrad König.

Schleswig=Holsteinische Schulzeitung. Landesbibliothek SH, Kiel.

Wienbarg, Ludolf (1834/1980): Soll die plattdeutsche Sprache gepflegt oder ausgerottet werden? Gegen Ersteres und für Letzteres. Niederdeutsch gestern - Eine Sprache in Pro und Contra, ed. by Claus Schuppenhauer. Leer: Schuster.

\section{Secondary Sources}

Arendt, Birte (2010): Niederdeutschdiskurse. Spracheinstellungen im Kontext von Laien, Printmedien und Politik. Berlin: Erich Schmidt.

Bichel, Inge/Bichel, Ulf/Hartig, Joachim (1994): Klaus Groth. Eine Bildbiographie. Heide: Westholsteinische Verlagsanstalt Boyens.

Bracker, Jochen (1972/73): "Die dänische Sprachpolitik 1850-1864 und die Bevölkerung Mittelschleswigs." Zeitschrift der Gesellschaft für Schleswig-Holsteinische Geschichte 97: 127-126 and 98: 87-214.

Chytraeus, Nathan (1582): Nomenclator latinosaxonicus. Rostock: Mylander.

Eco, Umberto (1994): Die Suche nach der perfekten Sprache. München: C.H. Beck.

Fredsted, Elin (2003): "Language contact and bilingualism in Flensburg in the middle of the 19th century." In: Braunmüller, Kurt/Ferraresi, Gisella (eds.) (2003): Aspects of Multilingualism in European Language History. Amsterdam/Philadelphia, Benjamins: 3560 .

Gardt, Andreas (1999): Geschichte der deutschen Sprachwissenschaft. Berlin/New York: De Gruyter.

Hansen, Nils (1991): "Schleswig-holsteinische Visitationsberichte des 19. Jahrhunderts als volkskundliche Quellen". Kieler Bläiter zur Volkskunde 23: 103-112. 
Hopster, Norbert/Wirrer, Jan (1994): "Tradition, Selbstinterpretation und Politik. Die 'Niederdeutsche Bewegung' vor und nach 1933". In: Dohnke, Kay et al. (eds.) (1994): Niederdeutsch im Nationalsozialismus. Studien zur Rolle regionaler Kultur im Faschismus. Hildesheim/Zürich/New York, Georg Olms: 59-122.

Jones, William J. (1995): Sprachhelden und Sprachverderber. Berlin/New York, De Gruyter.

Langer, Nils (2003): "Low German". In: Deumert, Ana/Vandenbussche, Wim (eds.) (2003): Germanic Standardisations. Amsterdam, Benjamins 282-302.

Langer, Nils (2011): "Historical Sociolinguistics in Nineteenth-Century Schleswig Holstein Evidence from School Inspection Reports". German Life and Letters 64: 167-187.

Langer, Nils (2012): "Die Lesebuchfrage in Schleswig-Holstein (1864-1870)". In: Bär, Jochen/Müller, Markus (eds.) (2012): Sprachsystem und Sprachgebrauch in Geschichte und Gegenwart. Berlin, Akademie Verlag: 565-584.

Langhanke, Robert (2010): "Gorch Focks 'Hein Godenwind'. Ein Hamburger Märchenheld als idealer niederdeutscher Sprecher - 'een Hamborger Jung, dorch dat Vergreuterungsglas ankeeken'". In: Schütt, Rüdiger (ed.) (2010): Gorch Fock - Mythos, Marke, Mensch. Aufsätze zu Leben, Werk und Wirkung des Schriftstellers Johann Kinau (1880-1916). Nordhausen, Traugott Bautz: 61-106.

Langhanke, Robert (2011): "Mundartdichtung als Minderheitensprachenprojekt: Konzepte des niederdeutschen Kulturbetriebs in historischer Perspektive". In: Drahota-Szabó, Erzsébet/Propszt, Eszter (eds.) (2011): Über Sinn und Unsinn von Minderheitenprojekten. Szeged, Grimm: 89-109.

Lesle, Ulf-Thomas (1990): "Hamburg als 'Mittelpunkt und Kraftquell'. Die 'Niederdeutsche Bewegung' - ihre Voraussetzungen und Verbindungen. 'Liebe, die im Abgund [sic] Anker wirft'". In: Stephan, Inge/Winter, Hans-Gerd (eds.) (1990): Autoren und literarisches Umfeld im Hamburg des 20. Jahrhunderts. Berlin/Hamburg, Argument: 69-82.

Menke, Hubertus (1998): "Niederdeutsch: Eigenständige Sprache oder Varietät einer Sprache?". In: Schmitsdorf, Eva et al. (eds.) (1998): Lingua Germanica. Studien zur deutschen Philologie. Jochen Splett zum 60. Geburtstag. Münster, Waxmann: 171-184.

Menke, Hubertus (2001): "Een Spraak is man bloots een Dialekt, de sik to Wehr setten kann. Nachlese zur Diskussion um die Europäische Sprachenschutzcharta". In: Föllner, Ursula (ed.) (2001): Niederdeutsch. Sprache und Literatur der Region. Frankfurt, Lang: 9-33.

Petersen, Thomas Peter (1995): Preußens Sprachpolitik in Nordschleswig. Münster: WW Universität.

Rohweder, Jürgen (1976): Sprache und Nationalität. Nordschleswig und die Anfänge der dänischen Sprachpolitik in der ersten Hälfte des 19. Jahrhunderts. Glückstadt: Augustin.

Scheuermann, Ulrich (2004): "Kirche und Schule contra Niederdeutsch im 18. und 19. Jahrhundert". In: Lehmberg, Maik (ed.) (2004): Sprache, Sprechen, Sprichwörter. Stuttgart, Steiner: 159-186.

Stammler, Wolfgang (1918): "Die niederdeutsche Literatur im 18. Jahrhundert". Niederdeutsches Jahrbuch 44: 57-71.

Stammler, Wolfgang (1920): Geschichte der niederdeutschen Literatur von den ältesten Zeiten bis auf die Gegenwart. Leipzig/Berlin: Teubner. 